\title{
ORGANIC FOOD CONSUMPTION IN THE APPROACH THEORY OF PLANNED BEHAVIOUR
}

\author{
Putra I Komang Trisna Eka*, Utama I Made Suyana \\ Faculty of Economics and Business, University of Udayana, Bali, Indonesia \\ ${ }^{*}$ E-mail: komangeka9@gmail.com
}

\begin{abstract}
The issue of food safety, nutritional content and environmental friendliness is a growing issue in the food industry. The issue of food safety has increased public awareness of the environment which requires everyone to have a healthy lifestyle by consuming organic food. The purpose of this research is to get an in-depth picture of the behavior of consuming organic food in the theory of planned behavior approach. The research method used in this study is a literature review. The result of this research shows how the theory of planned behavior (TPB) works which states that the consumption of organic food is influenced by the intention to consume organic food while the intention to consume organic food is influenced by the attitude, subjective norms, and perceived behavioral control. The modified TPB improved the model's ability to predict organic consumption intentions compared to the unmodified TPB model. The modified TPB model shows that increased organic food consumption can lead to increased awareness of health and behavior related to the environment.
\end{abstract}

\section{KEY WORDS}

Organic food, consumption behavior, theory of planned behavior.

These days, the agricultural production needs to be carried out by considering food security and environmental protection and preservation. Food is the main source of nutrition for humans as well as a basic medicine that helps maintain and restore one's health. The main supplier of "living food" is organic agriculture Toncea, at al., (2020). Consumption of organic food can increase business opportunities in this area, by creating significant benefits for the economy. Food safety, nutritional attributes, and environmentally friendly (ecolabeling) are several issues in the food industry. The issue of food safety has increased public awareness of the environment, which requires everyone to have a healthy lifestyle and tend to be natural (Chan, 2001). The increasing need for quality food and health sector is formed because of the belief that healthy and natural food can reduce the prevalence of various diseases (Nord, 2009). This phenomenon has led to the demand and consumption of products related to health care (Syahlani, 2006; Worsley \& Scott, 1999), especially organic food that is free from hazardous chemicals.

The results of the YLKI research survey (2012) show that the consumption level of organic food in several regions in Indonesia is low. The reasons for consumers not buying organic food include high prices, distribution problems and sales locations that are difficult to access to get organic food. Some consumers don't know about organic food. Access factors and distribution locations are still the main problems for consumers to obtain organic food products. Several studies related to environmentally friendly consumers have attempted to reveal the factors that determine the buying behavior of environmentally friendly food products. A review of the results of research on organic food consumer behavior classifies the determinant factors for organic food purchasing behavior, namely consumer value (Chan, 2001; Chan \& Lau, 2000; Fraj \& Martinez, 2006), knowledge (Chan, 1999; Chan \& Lau, 2000; Magistris \& Gracia, 2008), consumer attitudes (Aertsens et al., 2009; Gracia \& Magistris, 2007; Lodorfos \& Dennis, 2008; Wijaya \& Suprapto, 2012a), subjective norms (Wijaya, 2012a; Aertsens et al., 2009; Lodorfos \& Dennis, 2008; Sampson, 2009), behavior control (Aertsens et al., 2009; Lodorfos \& Dennis, 2008; Tarkiainen \& Sundqvist, 2005; Wijaya, 2012a). These variables are categorized as values, knowledge, attitudes and 
behavior (Chan \& Lau, 2000; Chan, 2001; Follows \& Jobber, 2000) which refers to the basic model of planned behavior theory.

In 1985, Ajzen developed the theory of planned behavior ("TPB") and in Ajzen's later paper (1991) he developed a framework for predicting behavior in a particular context. He found that behavioral intentions were predicted with a high degree of accuracy by three factors: personal attitudes toward the behavior, subjective norms and perceived behavior control. The theory of planned behavior has become one of the most influential models for predicting human social behavior, Ajzen (2011). There are authors who use planned behavior theory to analyze consumer behavior of organic food products and consider it a good starting point for modeling consumer behavior.

The concept of food has a value for consumers. Value is also considered to identify consumer segmentation, especially in environmentally friendly products (Engel et al, 2005; Fraj \& Martinez, 2006). Value becomes the basic reference for consumers in making decisions regarding the consumption of environmentally friendly products. Value is part of consumer belief to behave and behave, while knowledge is used in evaluating or considering in decision making. Several studies have shown the effect of value on green consumer attitudes, such as Chan (2001) and Chan \& Lau (2000). In addition to the value aspect, the consumer knowledge factor also needs to be considered in consumer behavior research because it relates to purchase considerations. Lodorfos \& Dennis (2008) suggest the importance of information as part of green consumer decision making. Attitudes which are a basic component in the theory of planned behavior are determined by the level of individual belief and can change according to the level of knowledge (Aertsens et al, 2009). The aspect of consumer knowledge is one of the considerations for consumers in evaluating products. Product knowledge shows how much product information has been absorbed by consumers (Engel et al, 2005). Consumers who are knowledgeable about products will ignore the premium price of environmentally friendly products to be consumed. Gracia \& De Magistris (2007) revealed that consumer knowledge is a consideration for consumers in distinguishing the attributes of organic products from other conventional products, as well as consumer evaluations of organic products. Several studies indicate a partial role for organic knowledge on consumption behavior of organic products (Poelman et al., 2008; Schlegelmilch et al., 1996; Junaedi, 2006; Gracia \& Magistris, 2007; Magistris \& Gracia, 2008; Amyx et al, 1994; Vining \& Ebreo, 1990; Chan, 1999; Yiridoe et al., 2005). This study extends the research of Sampson (2009), Lodorfos \& Dennis (2008), Kalafatis et al., (1999), Chiou (1998) and Tarkiainen \& Sundqvist (2005). Kalafatis et al., (1999) who used a model theory planned of behavior in predicting purchase intention in the Netherlands and Greece. Previous research did not involve value aspects or consumer knowledge comprehensively as background factors in the expansion of the modified theory planned behavior model. The thing that underlies the importance of aspects of value and knowledge in purchasing behavior is based on the opinion that knowledge, attitudes, and values will help in creating concern, attention and consumer behavior that is friendly to the environment (Umberson, 2008; Bui, 2005; Mansaray \& Abijoye, 1998; Chen \& Chai, 2010).

Based on the foregoing, this paper is to answer the behavior of consuming organic food, where the main model adopts Theory Of Planned Behavior (TPB). This TPB construct (Ajzen, 1991) includes the attitude of consuming organic food, subjective norms, and behavioral control in explaining the intention to consume organic food. Most of the studies analyzed the relationship between the theory of planned behavior and several theories of customer values. Health awareness and environmental concern are most often analyzed in combination with TPB. Some researchers (Singh: 2017, Bagher: 2018, Wang: 2019, Paul: 2016), propose the addition of other relevant variable models and use them in predicting purchase intentions as the direction of future research. The purpose of this paper is also to find out how the behavior of consuming organic food combines the theory of planned behavior with health awareness, environmental awareness, the value of natural human orientation, and knowledge. 


\section{METHODS OF RESEARCH}

This research method uses a literature review. Literature reviews contain reviews, summaries, and writers' thoughts on several literature sources (articles, books, slides, information from the internet, etc.) on the topics discussed, a good literature review must be relevant, up to date, and adequate.

\section{RESULTS AND DISCUSSION}

Based on the theoretical framework built from the modified planned behavior theory, the conceptual model in the form of a general framework in this study illustrates that background factors consisting of personal, social and information factors determine behavioral attitudes. Furthermore, attitude to behave, subjective norms and behavior control along with actual behavior control will influence the intention to behave and ultimately will affect actual behavior. Background factors are basic factors that are antecedents of behavioral attitudes, including personal, social and information factors. Personal factors are characteristics or traits inherent in individuals including personality traits, values and emotions of the individual. Personality traits are a pattern of characteristics or traits that are relatively persistent and unique characteristics that determine individual behavior consistently and distinctively (Santrock, 2005) such as introversion, extraversion, instability, and stability. Values give direction to a person's attitudes, beliefs and behavior, and provide guidelines for selecting the desired behavior in each individual. The five categories of consumer value orientation are man-himself (human) orientation, man-nature orientation, relational orientation, past-time (time) orientation, and activity orientation. This value orientation is specifically related to consumer behavior (Churchill, 1979; Engel et al, 2005). The value related to environmentally friendly behavior is the value of human nature orientation (Chan, 2001).

Social factors are characteristics that have associations with individual social groups including age, gender, race, education, income, and religion. The factors tend to be aspects of individual demographics that are recognized by the social environment. Age, gender, race, education, income and religion are groupings of individuals that are accepted by the social environment. The information factor is an aspect of cognition or the information content inherent in an individual including experience, knowledge and media exposure. Experience is concerned with the involvement of the subject in relation to psychological objects. Knowledge is all information that consumers have about various kinds of products, as well as other related knowledge and information related to their role as consumers. Consumer knowledge is divided into three types, namely product knowledge, purchasing knowledge and usage knowledge. According to Engel et al (2005) product knowledge is a collection of various kinds of information about products. Knowledge includes terminology, product categories, and product attributes. This type of product knowledge is categorized as knowledge about the characteristics or attributes of the product, knowledge about the benefits of the product and knowledge about the satisfaction that the product provides to consumers. Theory of Planned Behavior (hereinafter abbreviated as TPB, put forward by Ajzen (1991). This theory states that the central factor of individual behavior is that the behavior is influenced by the individual's intention towards that particular behavior. Intention to behave is influenced by attitude variables. ), subjective norms, and perceived behavioral control.

\section{Health Awareness}

According to Yang., Et al (2014), awareness of health is defined as an attitude where people realize the importance of health in their diet and lifestyle. Health awareness refers to the degree to which health care is integrated into a person's daily activities (Jayanti and Burns, 1998). Health awareness is considered as a subjective intention or motivation to improve individual health. When associated with the organic food context, it can be concluded that a positive attitude towards organic food by consumers comes from the belief that organic food is good for health, thus they can consume without fear and worry (Suh et al., 2012). 
Environmental awareness is an effort that involves every citizen in growing and fostering awareness to preserve the environment based on values, namely the values of the environment itself with a philosophy of living peacefully with its natural environment (Neoloka, 2008). The basic cause of environmental awareness is environmental ethics. The current environmental ethics is environmental ethics based on a value system that places humans as not part of nature, but humans as conquerors and regulators of nature. In environmental education, the mental concept of humans as conquerors of nature needs to be transformed into humans as part of nature (Neoloka, 2008). According to Albayrak et al. (2013) in his research measuring concern or awareness of the environment measured from three dimensions, consisting of egoistic care, altruistic concern and biosperic concern.

Environmental awareness according to (Mohammed Bilal Basha., 2015) has a positive influence on consumer attitudes to buy organic food, the strongest reason for consumers is that consumers buy organic food because consumers care about the environment, that a healthy environment affects consumers in decision making and consumers know the organic food process is managed, this is what motivates consumers to buy organic food. (Irianto, 2015) found that environmental awareness is very important in making decisions to buy organic food because organic food cultivation is carried out by taking environmental aspects that involve the use of organic compost and manure, and natural pest and disease control that leads to minimizing negative effects on the environment. Knowledge about the environment and concern possessed by consumers today is one of the reasons many companies have started to develop environmentally friendly systems in their products. In addition, the level of knowledge of these consumer products will determine their purchase intention and indirectly influence their purchasing decisions (Suparna, 2015).

Organic food as an environmentally friendly product is part of an individual belief system (Dembkowski \& Lloyd, 1994). The belief in the benefits of food and nutrition is part of culture for several nations in Asia such as China, Japan, Korea and several other countries (Verschuren, 2002; Westrate, 2002). Values are considered important by a group of people because they play a role in directing behavior. In individual behavior is directed by values that are in accordance with the culture of the individual. Consumers of environmentally friendly products contain values that are oriented towards the relationship between humans and nature so that they consider the impact of consumption on the environment more. In general, consumer value can be divided into several types, namely man-nature orientation, man-himself orientation, relational orientation, past-time orientation, and activity orientation. The type of value according to Kluckhohn and Strodtbeck (1961) that is able to predict the buying behavior of environmentally friendly products is a natural human orientation that focuses on human relationships with nature and life in harmony with their environment. Asians see themselves as part of nature and live in harmony with nature or nature-oriented (de Mooij, 2004) what Chan (2001) calls natural human orientation (Man Nature Orientation). Several studies demonstrate consumer value has a positive influence on consumer attitudes towards organic products (Dreezens et al.,2005; Krystallis et al., 2008; Grunert \& Juhl, 1995; Durham \& Andrade, 2005; Kuhar \& Juvancic, 2005; Midmore et al., 2005 ;; Padel \& Foster, 2005; Verhoef, 2005; Gracia \& de Magistris, 2007; Stobbelaar et al., 2007). Human natural orientation leads to the relationship between humans and nature so that consumers try to find or obtain information related to environmental problems. Thus consumers who have a natural human value orientation will have attitudes that support consumption of organic products (Wijaya \& Hidayat, 2011; Wijaya \& Suprapto, 2012b).

Knowledge is one of the characteristics that influence the decision making process. Knowledge is a relevant factor that influences consumers in collecting and organizing received information (Alba \& Hutchinson, 1987), using information received for decision making and using information as an evaluation of products to be consumed (Martin \& Simintras, 1995). Consumer knowledge is all information that consumers have about various kinds of products, as well as other related knowledge and information related to their role as consumers (Engel et al, 2005). Peattie (1998) explains the green marketing concept analogy, that consumers who have good knowledge have a tendency to purchase environmentally friendly products. Consumers who are aware of the importance of purchasing impacts prefer 
to buy organic food (Follows \& Jobber, 2000; Vlosky et al, 1999; Bui, 2005; Laroche et al, 2001). Knowledge about organic food serves as a consideration for consumers to determine attitudes towards organic food (Amyx et al., 1994; Chan, 1999; Yiridoe et al., 2005; Poelman et al., 2008; Schlegelmilch et al., 1996; Junaedi, 2007 ; Gracia \& Magistris, 2007; Magistris \& Gracia, 2008). Consumers who are knowledgeable about organic food have a positive attitude compared to other consumers by evaluating that organic food is beneficial for consumers. Consumers evaluate products in the form of benefits obtained from organic food such as health, naturalness, and safety of consumption. Organic knowledge represents the ability of consumers to identify organic or non-organic products to form a positive attitude towards organic products (Magistris \& Gracia, 2007).

According to Ajzen (2005), attitude is a disposition to respond favorably or unfavorably to objects, people, instances or events. According to Assael (2001) attitudes are defined as the tendency to learn to respond to objects or object classes consistently both in likes and dislikes. . Meanwhile, according to Mowen and Minor (2002) attitude is an affection or feeling towards a stimulus. Based on the two definitions above, attitude can be explained that attitude is a learned tendency to respond to or receive stimuli to objects consistently both in likes and dislikes. Several concepts such as the theory of reasoned action and planned behavior explain that attitude is an accurate predictor of behavior through the intention variable. The formation of intention to behave can be explained by the theory of planned behavior which assumes that humans always have a purpose in behaving (Fishbein \& Ajzen, 1975). Attitude is a major component of intention formation. Attitude is formed from two main components, namely belief and evaluation. The more positive the individual's belief, the more positive the individual's attitude will be, and vice versa (Fisbein \& Ajzen, 1975). The results of consumer behavior research confirm the positive influence of consumer attitudes on intention to consume organic food (Chan, 1999; Chan \& Lau, 2000; Wijaya, 2011; Gracia \& Magistris, 2007; Kalafatis et al., 1999; Chiou, 1998; Aertsens et al. al., 2009; Tarkiainen \& Sundqvist, 2005; Sampson, 2009).

Subjective Norms are social influences that influence a person to behave. A person will have a desire for an object or behavior if he is influenced by the people around him to do so or he believes that the environment or the people around him support what he is doing. Hogg and Vaughan (2005) state that subjective norms are the product of individual perceptions of other people's beliefs. Subjective norms, namely individual beliefs to obey the directions or suggestions of those around them to participate in carrying out activities. Ramayah et al (2005) stated that subjective norms were measured using a subjective norm scale with indicators of family role belief in starting a business, confidence in partner support in business, belief in support from lecturers, belief in support from successful entrepreneurs, and belief in support in business from people who are considered important. Subjective norms are another factor that influences intention in the model proposed by Fishbein and Ajzen (1975). The main component in subjective norms is the willingness of individuals to comply with stimulants from the reference group. The higher the motivation of the individual to comply with the reference group in buying organic food, the higher the intention to buy organic food. Social factors in the form of factors around the individual play a role as a social function for consumers such as reference group, family, and role and status (Engel et al, 2005). The reference model has a role for consumers to determine product and brand choices. Family, as part of the consumer purchasing organization that is closest to consumers, is the primary reference group that is most influential in purchasing, especially in Indonesia. Reference factors become part of consumers to make purchases.

In the TPB model, Perceived behavioral control ("PBC") refers to a person's perception of whether or not it is difficult to carry out the desired behavior, related to the belief that the resources and opportunities needed to realize certain behaviors are available or not, Ajzen (1991). Perceived behavioral control is a measure of the extent to which individuals believe about how easy or difficult it is to display certain behavior (Hogg and Vaughan, 2005). This definition is also in accordance with the TPB model developed by (Francis et al., 2004). PBC is defined as a person's perception of his ability to carry out a behavior. In it, there are two aspects that are considered, first, how much the person has control over a behavior 
(controllability), and second, how confident that person feels capable of performing a behavior (self-efficacy). PBC has two influences, namely the influence on the intention to behave and the direct influence on behavior.

Another factor in the theory of planned behavior is perceived behavior control. This factor describes a condition in which individuals believe that a behavior is easy or difficult to do. Individual consideration includes past experiences in addition to existing obstacles, which are considered by the individual. Behavioral control is influenced by the realistic constraints perceived by the individual. The degree or level of behavior control ability depends on individual beliefs about the availability of resources or opportunities from the environment to behave. The more resources and opportunities that are believed to be controlled by the individual, the higher the intention to behave (Ajzen, 1991). The results of the study confirmed that there was a positive relationship between behavior control and purchase intention of organic food (Kalafatis et al., 1999; Aertsens et al., 2009; Wijaya \& Hidayat, 2011; Wijaya \& Suprapto, 2012a). Regarding buying behavior of organic food, consumers consider factors that are considered to make buying organic food easier or more difficult, such as availability in the market, food prices, consumer financial aspects, and the existence of product authenticity (validity) information. Behavioral control has a direct role on behavior (Ajzen, 2005; 2008). Behavior is determined by individual beliefs about the availability of resources and opportunities associated with certain behaviors. If the individual has high perceived behavioral control, the individual will have a tendency to take actions that need to be done. Several research results indicate a direct relationship between behavioral controls such as price (Junaedi, 2006), income (Taner \& Kast, 2003) and buying behavior of organic food. The buying behavior of organic food is determined by factors that directly facilitate or make it difficult for consumers to buy organic food.

Ajzen (2005) defines intention as a behavior disposition, which until there is the right time and opportunity, will be manifested in the form of action. Intention is also defined as an internal declaration to act (Hogg and Vaughan, 2005). Suprapti (2010: 148) states that purchase intention can be used to predict future behavior. This means that if a consumer shows high purchase intentions, it can be assumed that he will make an actual purchase. Therefore, marketers have an interest in identifying consumer purchase intentions. Istiana et al. (2010) stated that subjective norms and behavioral control have an effect on purchase intentions, but attitudes have no effect on purchase intentions. The intention to buy has a significant effect on buying behavior. Furthermore, the behavioral control variable also has a direct effect on buying behavior. Yulianti (2012), the results of the study indicate that subjective norm attitudes and behavior control have a significant effect on purchase intention. The results of the study lead to the understanding that the ability of planned purchase theory in predicting purchasing behavior increases with increasing product relevance for respondents. The theory of planned behavior and the theory of reasoned action explain that individual behavior can be predicted through intention (Azjen, 2008). This is consistent with Ajzen and Madden (1986) who explained that intention plays a role in behavior because intention is seen as an intermediary for motivational factors that have an impact on a behavior, intention shows how hard a person dares to try (effort), intention also shows how much effort is planned. someone to do, and intention is the main symptom associated with subsequent behavior. Several research findings support the proposition of the relationship between purchase intention and buying behavior of organic food (Chan, 2001; Chan \& Lau, 2000; Bui, 2005, Follows \& Jobber, 2000; Magnusson et al, 2001). Intention acts as an intermediary for the influence of various factors that impact behavior. Intention plays a distinctive role in directing action, namely connecting the deep consideration that a person believes and wants with certain actions.

\section{CONCLUSION AND SUGGESTIONS}

Based on the above discussion, it can be concluded that the planned behavior theory states that the behavior of consuming organic food is significantly influenced by the intention to consume organic food and the intention to consume organic food is influenced by 
attitudes, subjective norms and perceived behavioral control. As found in other studies (Asif: 2017), Singh: 2017, Maichum: 2016, Arvola: 2008).

As food chains grow and change exponentially, the importance of exploring how and why decisions about food consumption are made are of great importance. This study was conducted to provide insight into the factors that explain organic food consumption using a modified version of TPB. Due to the importance of decision making in consuming organic food the modified version of TPB in addition to: health awareness, knowledge of organic food, environmental awareness, and the value of human orientation.

Other findings also reveal that organic consumer attitudes, descriptive norms, perceived behavioral control, income, and price are significant predictive variables of intention to consume organic. The modified TPB model, which includes descriptive norms, improves the model's ability to predict organic consumption intentions compared to the unmodified TPB model, which does not include descriptive norms. According to literature review, increased organic food consumption can lead to increased health awareness and behaviors related to health, the environment and ecological sustainability, and most importantly, pro-environmental behavior.

The limitation of this study is that this study only uses literature studies with a qualitative approach and has not yet discussed in detail what is happening in the field. So that further research can take samples at a location and test the application of the TPB theory with a quantitative approach.

\section{REFERENCES}

1. Ajzen, I. 1991. The theory of planned behavior. Organizational Behavior and Human Decision Processes. Vol 50, pp 179-211.

2. Ajzen, I. 2002. Perceived behavioral control, self-efficacy, locus of control, and the theory of planned behavior. Journal of Applied Social Psychology, Vol 32, pp. 665-683.

3. Ajzen, I. 2005. Laws of human behavior: Symmetry, compatibility, and attitude- behavior correspondence. In A. Beauducel, B. Biehl, M. Bosniak, W. Conrad, G. Schonberger, and D. Wagener (Eds.), Multivariate Research Strategies, Aachen, Germany: Shaker Verlag. pp. 3-19.

4. Albari, and Anita Liriswati. 2004. Analisis Minat Beli Konsumen Sabun Cair Lux, Biore, and Lifebuoy di Kota Madya Yogyakarta Ditinjau dari Pengaruh Sikapnya Setelah Melihat Iklan di Televisi and Norma Subyektif, Jurnal Siasat Bisnis, Vol 2, pp. 215-239.

5. Anssi, Tarkiainen and Sanna, Sundqvist. 2005. Subjective norms, attitudes and intentions of Finnish consumers in buying organic food, British Food Journal, Vol 107, pp. 808-822.

6. Ariani, M. 2005. Penguatan Ketahanan Pangan Daerah untuk Mendukung Ketahanan Pangan Nasional. Monograph Series. No. 26. Pusat Analisis Sosial Ekonomi and Kebijakan Pertanian. Badan Litbang Pertanian.

7. Armitage, C.J., and M. Conner. 2001. Efficacy of the theory of planned behaviour: ametaanalytic review. The British Journal of Social Psychology. Vol 40, pp. 471-99.

8. Arvola, A.; Vassallo, M.; Dean, M.; Lampila, P.; Saba, A.; Lähteenmäki, L.; Shepherd, R. Predicting intentions to purchase organic food: The role of active and moral attitudes in the theory of planned behaviour. Appetite 2008, 50, 443-454.

9. Asif, M.; Xuhui,W.; Nasiri, A.; Ayyub, S. Determinant factors influencing organic food purchase intention and the moderating role of awareness: A comparative analysis. Food Qual. Pref. 2018, 63, 144-150.

10. Bagher, A.N.; Salati, F.; Ghaari, M. Factors Aecting Intention to Purchase Organic FoodProducts among Iranian Consumers. Acad. Market. Stud. J. 2018, 22. Available online: https://www.semanticscholar.org/paper/Factors-Aecting-Intention-to-PurchaseOrganic-Bagher-Salati/662e9cd3d15b0e37b1ba978129dde632c90612be (accessed on 23 January 2020).

11. Burhanudin. 2006. Theory of Planned Behavior: Aplikasi pada Niat Konsumen untuk Berlangganan Surat Kabar Harian Kedaulatan Rakyat di Desa Donotirto, Kecamatan Kretek, Kabupaten Bantul. Jurnal Manajemen and Kewirausahaan, Vol.12, pp. 12-21. 
12. Chen, T.B and Chai, L. T. 2010. Attitude towards the environment and green product: consumer perspective, Management Science and Engineering, Vol. 4. No.2. pp. 27-39.

13. Chung, Joe Eun and Hee Yeon Kim. 2011. Consumer Purchase Intention for Organic Personal Care Product, Journal of Consumer Marketing, Vol.28. No.1, pp. 40-47.

14. Cooper, D.R., and P.S. Schinder. 2003. Business Reserch Methods. Eight Edition. New York : McGraw-Hill//rwin.

15. Dharmmesta, B. S. 2003. Sikap and perilaku konsumen dalam pemasaran : Sebuah tinjauan sosial kognitif. Yogyakarta : Kajian Bisnis STIE Widya Wiwaha. No. 29 MeiAgustus 2003.

16. Dewi, Febriantina, Yusalina. 2011. Aplikasi Theory Of Planned Behavior pada Analisis Perilaku Konsumen Beras Organik di Kota Bogor. Prosiding Seminar Penelitian Unggulan Departemen Agribisnis. Desember, 7-14, 2011. Bogor.

17. Engel, J.F., Roger, D.B., \& Paul, W. M. 2001. Consumer behavior. International Edition, Forth Worth: Dreyden Press.

18. Ferdinand, Augusty, 2006. Structural Equation Modeling Dalam Penelitian Manajemen: Aplikasi Model-model Rumit Dalam Penelitian untuk Tesis Magister and Disertasi Doktor, Edisi 4. Semarang: Badan Penerbit Universitas Diponegoro.

19. Francis, Jillian J., Martin P Eccles, Marie Johnston, Anne Walker, Jeremy Grimshaw, Robbie Foy, Eileen F S Kaner, Liz Smith, Debbie Bonetti. 2004. Constructing Questionnaires Based On The Theory of Planned Behaviour: A Manual for Health Services Researchers, Centre for Health Services Research, United Kingdom: University of Newcastle.

20. Gaddam, Soumya. 2008. Identifying the Relayionship Between Behavioral Motives and Entrepreneurial Intentions: An Empirical Study Based Participations of Business Management Students. The Icfaian Journal of Management Research. Vol.7, pp. 35-5.

21. Ghozali, Imam, 2008. Persamaan Struktural, Konsep, and Aplikasi dengan Program AMOS Ver.5.0. Semarang : BP UNDIP

22. Gracia, A., and Magistris, T. 2007. Organic food product purchase behaviour: a pilot study for urban consumers in the South of Italy, Spanish Journal og Agricultural Research,Vol. 5, No. 4, pp. 439-451.

23. Hartari, A. 2005. Atribut Produk and Karakteristik Konsumen Beras Organik terhadap Sikap Konsumen Beras Organik. Tesis, Bogor: Program Pascasarjana Manajemen and Bisnis, Institut Pertanian Bogor.

24. Hogg, M., and Vaughan, G. 2005. Social Psychology (4th edition). London: Prentice-Hall.

25. Honkanen, Pirjo. 2006. Ethical values and motives driving organic food choice. Journal of Consumer Behaviour. Vol. 5, pp. 420-430.

26. Istiana, Laili., Syahlani, Suci Paramitasari, and Nurtini, Sudi. 2010. The Effect of Attitude, Subjective Norm and Behavioral Control on Intention and Buying Behavior of Ultra High Temperature Milk Product. Semiloka Nasional. Yogyakarta: Universitas Gajah Mada. pp. 507-152.

27. Izhar, Hence. 2010. Analisis Sikap Konsumen Terhadap Atribut Sabun Mandi (Studi Pada Sabun Mandi Merek Lux and Giv di Kota Malang). Malang : Universitas Brawijaya. Vol. 13, No. 4, pp. 23-36.

28. Jaafar, Siti Nurafifah. 2010. Consumers' Perceptions, Attitudes and Purchase Intention towards Private Label Food Products in Malaysia, Asian Journal of Business and Management Sciences, Vol. 2, pp. 73-90.

29. Schiffman, L.G. and L.L. Kanuk. 2007. Consumer Behaviour. Ninth Edition. New Jersey: Prentice Hall International.

30. Simamora, Bilson. 2004. Riset Pemasaran, Falsafah, Teori and Aplikasi. Jakarta: PT. Gramedia Pustaka Utama.

31. Singh, A.; Verma, P. Factors influencing Indian consumers' actual buying behaviour towards organic food products. J. Cleaner Prod. 2017, 167, 473-483.

32. Solomon, M. R. 2007. Consumer Behaviour : Buying, Having, and Being. Seventh edition. New Jersey: Prentice Hall. 
33. Surya Pradipta and Suprapti, Ni Wayan Sri. 2013. Perilaku Konsumen:Pengaruh Sikap and Norma Subyektif terhadap Niat Calon Pemilih di Kota Denpasar untuk Memilih Partai Demokrat dalam Pemilu Legislatif Tahun 2014. Jurnal Manajemen, Strategi Bisnis, and Kewirausahaan. Vol. 7, No. 1, pp. 29-38.

34. Sutanto R. 2002. Pertanian Organik Menuju Pertanian Alternatif and Berkelanjutan. Yogyakarta: Penerbit Kanisius.

35. Taner, C., and Kast, S.W. 2003. Promoting sustainable consumption: Determinants of green purchases by Swiss consumers. Psychology and Marketing. Vol. 20, No.10, pp. 883-902.

36. Tarkiainen, A., and Sundqvist, S. 2005. Subjective norms, attitudes and intentions of Finnish consumers in buying organic food. British Food Journal. Vol. 107, No.11, pp. 808822.

37. Tsakiridou, E, Boutsouki, C, Zotos, Y., \& Mattas, K., 2008. Attitudes and behaviour towards organic products: an exploratory study. International Journal of Retail and Distribution Management, Vol. 36, No. 2, pp. 158-175.

38. Vermeir, I., Verbeke, W. 2006. Sustainable Food Consumption : Exploring The Consumer "Attitude - Behavioral Intention" gap. Journal of Agricultural and Environmental Ethics. Vol. 19, pp. 169-194

39. Vermeir, I., Verbeke, W. 2007. Sustainable food consumption among young adults in Belgium: Theory of planned behaviour and the role of confidence and values. Ecological Economics Journal, Vol. 10, pp. 03-07.

40. Verbeke, W., Vermeir, I., Brunsø, K. 2007. Consumer evaluation of fish quality as basis for fish market segmentation. Food Quality and Preference Journal. Vol. 18, No.4, pp. 651-661.

41. Wijaya, Tony and Hidayat, A. 2011. Model intense pembelian makanan organik, Call for Paper Update Ekonomi, Akuntansi and Bisnis Indo Indonesia, Proceeding Fakultas Ekonomi UII,Yogyakarta.

42. Wijaya, Tony. 2013. Anteseden Perilaku beli Produk Ramah Lingkungan : Studi Perilaku Konsumen Makanan Organik. Jurnal Ekonomi and Bisnis. Vol. 7, No. 3, pp. 149-161.

43. Wijaya, Tony. 2014. Nilai and Pengetahuan sebagai Prediktor Intensi Membeli Makanan Organik. Jurnal Manajemen and Kewirausahaan, Vol.16, h.69-82.

44. Yulianti, F. S. 2012. The Application of Planned Behavior Theory to Predict the Consumption of Processed Body-Shaping Milk. (Online), (http://medpet.journal.jpb.ac.id/DOI:10.5398/medpet.2012.35.2.140)

45. YLKI., 2012, Survei Konsumen Organik Indonesia, (Online), (www.organicindonesia.org). 